\title{
ハイブリッドFRP積層体の支圧強度評価法に 関する実験的研究
}

\author{
上山 裕太 1 - 北根 安雄 2 ・松井 孝洋 3 - 近藤 富士夫 4 ・舘石 和雄 5 \\ 1学生会員 名古屋大学大学院 工学研究科土木工学専攻（†464-8603 愛知県名古屋市千種区不老町） \\ E-mail: ueyama.yuuta@d.mbox.nagoya-u.ac.jp \\ 2正会員 名古屋大学大学院准教授 工学研究科土木工学専攻（同上） \\ E-mail: ykitane@civil.nagoya-u.ac.jp \\ 3正会員 東レ株式会社 コンポジット技術第1部（†455-0024 愛知県名古屋市港区大江町9番地の1） \\ E-mail: Takahiro_Matsui@nts.toray.co.jp \\ 4正会員＼cjkstart東レ株式会社＼cjkstart東京本社ACM技術部（干103-8666 東京都中央区日本橋室町2-1-1） \\ E-mail: Fujio_Kondo@nts.toray.co.jp \\ 5正会員 名古屋大学大学院教授 工学研究科土木工学専攻（干464-8603 愛知県名古屋市千種区不老町） \\ E-mail: tateishi@civil.nagoya-u.ac.jp
}

\begin{abstract}
本研究は，ハイブリッドFRP部材のボルト接合部における支圧特性に関するデータの取得および評価を 目的とする. 強化繊維に炭素繊維とガラス繊維の両方を用いた積層構成の異なる5種類のハイブリッド FRP積層体，および，CFRP積層体，GFRP積層体を対象とし，Mottramらの提案する支圧試験法とピン接合 法による2種類の支圧試験を実施し, 得られた試験結果の比較を行うことにより, 強化繊維の種類や積層 構成の違いが支圧強度に与える影響を明らかにした。また，各積層体の材料圧縮試験を行うことにより， 繊維や積層構成によっては，支圧強度が圧縮強度に比べて約 $50 \%$ も低下することを明らかにした。さらに， 手締め程度のボルト軸力が支圧強度に与える影響についても検討を行い，ボルト軸力を導入することで支 圧強度が大幅に増加することを明らかにした。
\end{abstract}

Key Words : hybrid FRP, bearing test method, bearing strength, compressive strength, bolted joint

\section{1. 研究背景と研究の目的}

近年, 高度経済成長期に建設された鋼構造物では建設 から 40 60 年経過したことで老朽化が問題となってい る ${ }^{1) 22}$. 特に狭险で湿気がたまりや寸い部位である鋼橋 桁端部では，著しく腐食劣化が進行した構造物も存在し， 今後, 現在健全な鋼構造物にも腐食が発生寸る可能性が ある．したがって，腐食劣化が鋼構造物の重大な事故を 引き起こす前に, 構造物の性能を維持するための補修・ 補強対策をとる必要がある.

鋼構造物の補修・補強にはこれまで鋼材を使用した当 て板補修の適用が多かったが, 近年, 強化繊維とマトリ ックス樹脂で構成された複合材料の FRP を用いた補 修・補強が注目されている．FRP は優れた軽量性と耐食 性を有していることから，腐食部の補修には有利な材料 である，腐食が軽微で当て板補修が可能であれば，FRP を接着することによる補修が適用でき，腐食が激しく鋼
部材の取替えが必要な場合には, FRP 部材による取替え が検討できる，ただし，FRP を用いた鋼構造物の補修・ 補強工法の確立はなされておらず，実際の土木鋼構造物 の補修・補強に適用されている事例はまだ少ないのが現 状である. 特に，腐食した鋼部材を FRP 部材に取り替 える場合は，通常，既存の鋼部材と FRP 部材はボルト 接合により接合され，摩擦接合ではなく支圧接合となる. その際の, 支圧ボルト接合部耐力についても, 統一的な 設計法は存在しない ${ }^{3)}$. また，FRP は材料コストが高い といった課題もあるため, 材料生産・施工から維持管理 までを含めたライフサイクルコストの削減を追求し，土 木構造物の補修・補強に用いられることが望まれる.

そこで本研究では, 強化繊維に炭素繊維 (CF) とガ ラス繊維（GF）の両方を用いたハイブリッド FRP に着 目した. 炭素䋊維は比強度・比弾性率に優れた繊維であ り，優れた機械特性を有した繊維である. しかし，材料 コストが高いという課題がある。 一方，ガラス繊維は炭 
素繊維に比べて比強度・比弾性率は小さいが，材料コス トが低いという特徴がある。これら二つの䋊維を使用す ることで，互いを補完しあい，より広範囲の材料特性が 得られ，目的に応じた材料を設計することが可能とな る ${ }^{4}$. しかし, 異なる積層構成のハイブリッド FRP 部材 のボルト接合部における支圧特性の評価を行った研究は 少なく5，今後，ハイブリッド FRPを実構造物に適用し ていくためには，接合部に関する基礎的データが必要と なる.

本研究では, ハイブリッド FRP 部材のボルト接合部 における支圧特性に関するデータの取得および評価を目 的とする．そこで強化繊維に炭素繊維とガラス繊維の両 方を用いた積層構成の異なる 5 種類のハイブリッド FRP 積層体および，CFRP 積層体，GFRP 積層体を対象とし，

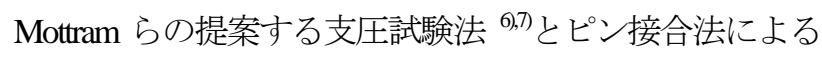
2 種類の支圧試験を実施し, 得られた試験結果の比較を 行うとともに強化繊維の種類や積層構成の違いが支圧強 度に与える影響を明らかにする．また，各積層体の材料 圧縮試験を行うことで, 支圧強度と圧縮強度の比較を行 う。さらに，手締め程度のボルト軸力を与えた接合部強 度実験を行うことで, 手締め程度のボルト軸力が支圧強 度に与える影響についても検討を行う。

\section{2. 試験に用いた積層体の概要}

本研究では, 強化繊維に炭素繊維とガラス繊維, マト リックス樹脂に引抜成形性, 経済性, 強化繊維の強度発 揮特性等を考慮してビニルエステル樹脂（エポキシアク リレート樹脂）を使用した FRP 積層体を用いる．使用 寸る強化繊維は, 取扱い性, 成形性からシート状の織物 形態にした強化繊維シートであり, UT70-60 が一方向平 織の高強度 CF シート, BT70-30 が二方向平織の高強度 CF シート, UM46-34 が一方向平織の中弾性 CF シート, GF-UD600 が一方向の GF シート, WR500 は二方向平織 の GF シートの 5 種類とした. 表-1 に強化繊維シートの 材料特性を示寸. また, 表-2 にマトリックス樹脂であ るビニルエステル樹脂の材料特性を示す.

CFRP 構造部材の成形法は, 断面形態, 量産性, 経済 性, 品質特性を考慮すると引抜成形法が最適だが，小口 ットでは生産設備等の初期投資が骨むため, 本研究では 引抜成形法と同等の䋊維含有量および機械特性を示すこ とができる VaRTM（Vacuum assisted Resin Transfer Molding) 成形を用いる。

本研究で用いる FRP 積層体の積層構成は表-3 に示し た 7 種類であり, それぞれ強化繊維の種類と割合, 繊維

表-1 強化䋊維シートの材料特性

\begin{tabular}{|c|c|c|c|c|c|}
\hline 種類 & 品番 & 目付け $\left(\mathrm{g} / \mathrm{m}^{2}\right)$ & 厚み( $(\mathrm{mm})$ & 引張強度 $\left(\mathrm{N} / \mathrm{mm}^{2}\right)$ & 弾性率 $\left(\mathrm{kN} / \mathrm{mm}^{2}\right)$ \\
\hline \multirow{3}{*}{ CFシート } & UT70-60 & 600 & 0.333 & 4900 & 245 \\
\cline { 2 - 6 } & BT70-30 & 300 & 0.167 & 4500 & 245 \\
\cline { 2 - 6 } & UM46-34 & 340 & 0.185 & 4200 & 440 \\
\hline \multirow{2}{*}{ GFシート } & UD600 & 645 & 0.253 & 3400 & 72 \\
\cline { 2 - 6 } & WR570 & 570 & 0.224 & 3400 & 72 \\
\hline
\end{tabular}

表-2 マトリックス樹脂の材料特性

\begin{tabular}{|c|c|c|c|c|c|c|}
\hline 名称 & 比重 $\left(\mathrm{g} / \mathrm{cm}^{3}\right)$ & 引張強さ $\left(\mathrm{N} / \mathrm{mm}^{2}\right)$ & 引張伸び率 $(\%)$ & 曲げ強度 $\left(\mathrm{N} / \mathrm{mm}^{2}\right)$ & 曲げ弾性率 $\left(\mathrm{kN} / \mathrm{mm}^{2}\right)$ & 熱変形温度 $\left({ }^{\circ} \mathrm{C}\right)$ \\
\hline R-804 & 1.13 & 80 & 4.6 & 135 & 3 & 105 \\
\hline
\end{tabular}

表-3 FRP積層体の積層構成

\begin{tabular}{|c|c|c|c|c|c|c|c|c|c|}
\hline & \multirow{2}{*}{ 方向 } & \multicolumn{7}{|c|}{ 試験体番号 } \\
\hline & & & 1 & 2 & 3 & 4 & 5 & 6 & 7 \\
\hline \multirow{4}{*}{ CFRP } & UT70-60 & $0^{\circ}$ & 5 & 0 & 0 & 0 & 0 & 0 & 0 \\
\hline & \multirow{2}{*}{ BT70-30 } & $0 / 90^{\circ}$ & 0 & 0 & 0 & 0 & 0 & 5 & 0 \\
\hline & & $\pm 45^{\circ}$ & 0 & 0 & 0 & 0 & 0 & 6 & 0 \\
\hline & UM46-34 & $0^{\circ}$ & 0 & 10 & 7 & 7 & 7 & 5 & 0 \\
\hline \multirow{3}{*}{ GFRP } & GF-UD600 & $0^{\circ}$ & 0 & 0 & 0 & 0 & 0 & 0 & 6 \\
\hline & \multirow{2}{*}{ WR500 } & $0 / 90^{\circ}$ & 4 & 4 & 0 & 4 & 6 & 0 & 3 \\
\hline & & $\pm 45^{\circ}$ & 2 & 2 & 8 & 4 & 2 & 0 & 4 \\
\hline \multirow{3}{*}{\multicolumn{2}{|c|}{ 方向の比率(\%) }} & $0^{\circ}$ & 69 & 70.8 & 40.1 & 55.1 & 62.5 & 57.2 & 59.2 \\
\hline & & $90^{\circ}$ & 15.5 & 14.6 & 0 & 15 & 22.5 & 12.6 & 11.2 \\
\hline & & $\pm 45^{\circ}$ & 15.5 & 14.6 & 59.9 & 29.9 & 15 & 30.2 & 29.6 \\
\hline \multirow{3}{*}{ 狙い } & \multicolumn{2}{|c|}{ CF種の違い } & 0 & 0 & & & & & \\
\hline & \multicolumn{2}{|c|}{ 450層の影響 } & & & 0 & 0 & 0 & & \\
\hline & \multicolumn{2}{|c|}{ CFとGFの違い } & & & & & & 0 & 0 \\
\hline \multicolumn{3}{|c|}{ 試験体板厚の平均值 (mm) } & 5.6 & 6.4 & 6.3 & 6.2 & 6.3 & 6.4 & 6.1 \\
\hline
\end{tabular}


方向の比率が異なる．試験体 1 から試験体 5 は炭素䋊維 とガラス繊維の両方を使用したハイブリッド FRP 積層 体である．試験体 1 と試験体 2 では炭素繊維の種類が異 なり, 試験体 2 の方がより高弾性な繊維を用いている. 試験体 3 から試験体 5 では, WR570 の 0/90方向および 土45方向の繊維の総数が異なる。また, 試験体 6 は CFRP 積層体，試験体 7 は GFRP積層体である.

また，これらの FRP 積層体の材料特性を得るために 引張試験，圧縮試験，面内せん断試験，層間せん断試験， 曲げ試験を各積層体で 5 体ずつ行った. 引張試験は土木 学会基準 JSCE-E 531-2007 に，圧縮試験は JS K 7018 に, 曲げ試験は JS K 7017 に，面内せん断試験は ASTM D 7078 に，層間せん断試験は JIS K 7057 に従って試験を行 った. ここでは材料座標系として一方向材の繊維方向を 1 方向（0॰方向），面内でそれに直交する方向を 2 方向
（90`方向），面外方向（板厚方向）を 3 方向と定義す る. 本研究では鋼構造物の軸力部材のボルト接合部にお ける軸方向の支圧特性に関するデータの取得および評価 を目的とするため 1 方向の支圧試験を行う．そこで，表 -4には材料試験で得られた 1 方向の引張特性, 圧縮特性, 曲げ特性，12 方向の面内せん断特性，13 方向の層間せ 儿断特性を示寸.

高強度 CF シート UT70-60 を使用した試験体 1 は, 中 弾性 CF シートを使用した試験体 2 と比較して, 引張強 度が 50\%，圧縮強度が 20\%大きい結果となった．また， WR570 の 0/90方向と $\pm 45^{\circ}$ 方向の層数を変化させた試験 体 3から試験体 5 の面内せん断試験結果を比較すると, 土45方向の層数が試験体 5 の 4 倍の試験体 3 は試験体 5 と比較して，弾性率は 66\%，強度は 29\%大きい結果とな った．繊維の違いに関しては，CFRP 積層体である試験

表-4 材料試験結果

(a)引張試験（1方向）

\begin{tabular}{|c|c|c|c|c|c|c|c|c|}
\hline \multicolumn{2}{|c|}{} & 試験体 1 & 試験体 2 & 試験体 3 & 試験体 4 & 試験体 5 & 試験体 6 & 試験体 7 \\
\hline \multirow{2}{*}{ 引張強度 } & 平均值(MPa) & 1428 & 943 & 624 & 736 & 748 & 884 & 600 \\
\cline { 2 - 11 } & 変動係数 & 0.020 & 0.068 & 0.107 & 0.145 & 0.086 & 0.034 & 0.023 \\
\hline \multirow{2}{*}{ 引張弾性係数 } & 平均值(GPa) & 82.0 & 145.6 & 96.1 & 110.9 & 116.5 & 128.2 & 25.8 \\
\cline { 2 - 10 } & 変動係数 & 0.064 & 0.045 & 0.023 & 0.036 & 0.063 & 0.046 & 0.052 \\
\hline
\end{tabular}

(b) 圧縮試験（1方向）

\begin{tabular}{|c|c|c|c|c|c|c|c|c|}
\hline \multicolumn{2}{|c|}{} & 試験体 1 & 試験体 2 & 試験体 3 & 試験体 4 & 試験体 5 & 試験体 6 & 試験体 7 \\
\hline \multirow{2}{*}{ 圧縮強度 } & 平均值(MPa) & 408 & 333 & 360 & 352 & 416 & 360 & 379 \\
\cline { 2 - 10 } & 変動係数 & 0.053 & 0.080 & 0.059 & 0.048 & 0.069 & 0.068 & 0.050 \\
\hline \multirow{2}{*}{ 圧縮弾性係数 } & 平均值(GPa) & 76.3 & 131.9 & 85.4 & 91.4 & 94.3 & 111.3 & 30.9 \\
\cline { 2 - 10 } & 変動係数 & 0.071 & 0.092 & 0.029 & 0.014 & 0.034 & 0.016 & 0.032 \\
\hline
\end{tabular}

(c) 層間せん断試験（13方向）

\begin{tabular}{|c|c|c|c|c|c|c|c|c|}
\hline \multicolumn{2}{|c|}{} & 試験体 1 & 試験体 2 & 試験体 3 & 試験体 4 & 試験体 5 & 試験体 6 & 試験体 7 \\
\hline \multirow{2}{*}{ 層間せん断強度 } & 平均值(MPa) & 36 & 29 & 36 & 34 & 36 & 36 & 35 \\
\cline { 2 - 10 } & 変動係数 & 0.016 & 0.021 & 0.012 & 0.031 & 0.055 & 0.026 & 0.032 \\
\hline \multirow{2}{*}{ 層間せん断弾性係数 } & 平均值(GPa) & 4.3 & 4.7 & 3.2 & 3.6 & 3.8 & 3.3 & 4.0 \\
\cline { 2 - 10 } & 変動係数 & 0.143 & 0.048 & 0.275 & 0.031 & 0.186 & 0.144 & 0.161 \\
\hline
\end{tabular}

(d) 面内せん断試験（12 方向）

\begin{tabular}{|c|c|c|c|c|c|c|c|c|}
\hline \multicolumn{2}{|c|}{} & 試験体 1 & 試験体 2 & 試験体 3 & 試験体 4 & 試験体 5 & 試験体 6 & 試験体 7 \\
\hline \multirow{2}{*}{ せん断強度 } & 平均值(MPa) & 96 & 89 & 128 & 123 & 99 & 143 & 150 \\
\cline { 2 - 10 } & 変動係数 & 0.079 & 0.093 & 0.041 & 0.017 & 0.018 & 0.062 & 0.039 \\
\hline \multirow{2}{*}{ せん断弹性係数 } & 平均值(GPa) & 5.3 & 5.3 & 8.4 & 6.7 & 5.0 & 12.6 & 5.9 \\
\cline { 2 - 10 } & 変動係数 & 0.012 & 0.031 & 0.019 & 0.065 & 0.024 & 0.093 & 0.061 \\
\hline
\end{tabular}

(e) 曲げ試験（1方向）

\begin{tabular}{|c|c|c|c|c|c|c|c|c|}
\hline \multicolumn{2}{|c|}{} & 試験体 1 & 試験体 2 & 試験体 3 & 試験体 4 & 試験体 5 & 試験体 6 & 試験体 7 \\
\hline \multirow{2}{*}{ 曲げ強度 } & 平均值(MPa) & 629 & 364 & 334 & 341 & 337 & 386 & 418 \\
\cline { 2 - 11 } & 変動係数 & 0.055 & 0.058 & 0.085 & 0.075 & 0.071 & 0.053 & 0.061 \\
\hline \multirow{2}{*}{ 曲げ弾性係数 } & 平均值(GPa) & 63.7 & 99.2 & 68.1 & 75.9 & 74.0 & 114 & 26.0 \\
\cline { 2 - 10 } & 変動係数 & 0.089 & 0.053 & 0.015 & 0.026 & 0.049 & 0.061 & 0.012 \\
\hline
\end{tabular}


体 6 と GFRP 積層体である試験体 7 の圧縮試験結果を比 較すると，圧縮弾性率は試験体 6 が試験体 7 の 3.6 倍で あるのに対して，圧縮強度は試験体 6 が試験体 7 よりも 5\%小さい結果となった。このような材料特性をもつ積 層体に対して，2 種類の支圧試験を行い，支圧強度の比 較を行う。

\section{3. 支圧試験方法}

本研究では Mottram 法による支圧試験と，比較用の試 験であるピン接合法による支圧試験の 2 種類の支圧試験 を行った. Mottram 法による支圧試験は表-3 に示す 7 種 類の積層構成全てに対して試験を行い，ピン接合法によ る支圧試験はハイブリッド FRP 積層体である試験体 5 と CFRP積層体である試験体 6 の 2 種類に対して試験を 行った.

\section{(1) ピン接合法による支圧試験}

ASTM D953 や EN 13706 で規定されている支圧強度試 験を参考にして行った試験方法を，本研究ではピン接合 法と呼ぶ. 図-1(a)と図-2(a)に示すように，FRP 試験体と 鋼製添接板，鋼製母板をステンレスボルト（M20）で接 合する．鋼製添接板と鋼製母板はステンレス鋼 SUS304 を用いている．FRP 試験体と鋼製添接板の間にスペース を空けることでピン接合とする. FRP 試験体と鋼製母板 のつかみ部を前川式万能試験機（最大荷重 $2,000 \mathrm{kN}$ ）で つかみ, 引張荷重を載荷する. つかみ部間の変位を変位 計で測定し，試験体の変位とみなす。試験は試験体 5 と 試験体 6 の積層体に対して, 各 3 体ずつ試験を行った.

また，図-3(a)にピン接合法支圧試験体の寸法を示す. 試験体がせん断破壊および引張破壊で破壊することを防 ぎ，確実に支圧破壊を生じさせるために，縁端距離をボ ルトの直径の 8倍, 試験体幅を 6倍とした. また，ボル 卜孔の直径は $21 \mathrm{~mm}$ とし，ボルト径 $20 \mathrm{~mm}$ に対し，1mm のクリアランスを設けている. 支圧面にボルトのねじ部

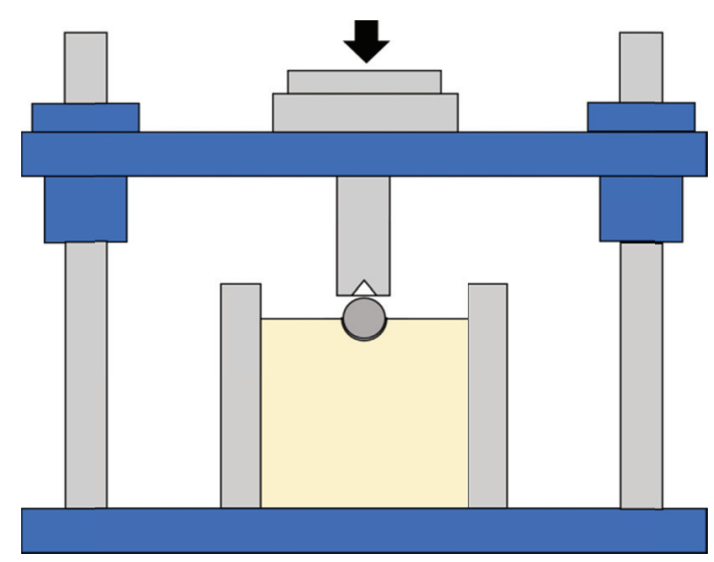

(b) Mottram 法による支圧試験

(a) ピン接合法による支圧試験

図-1 支圧試験方法の模式図

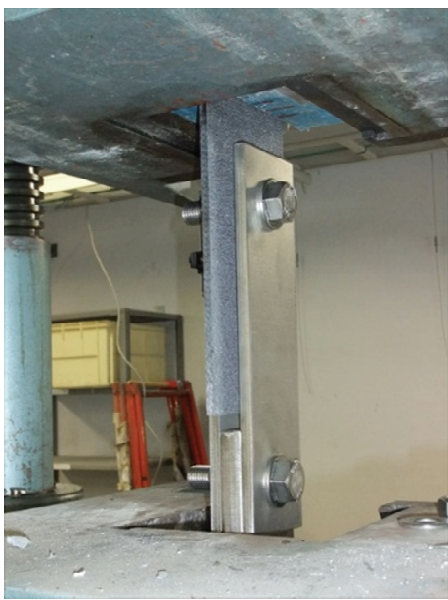

(a) ピン接合法

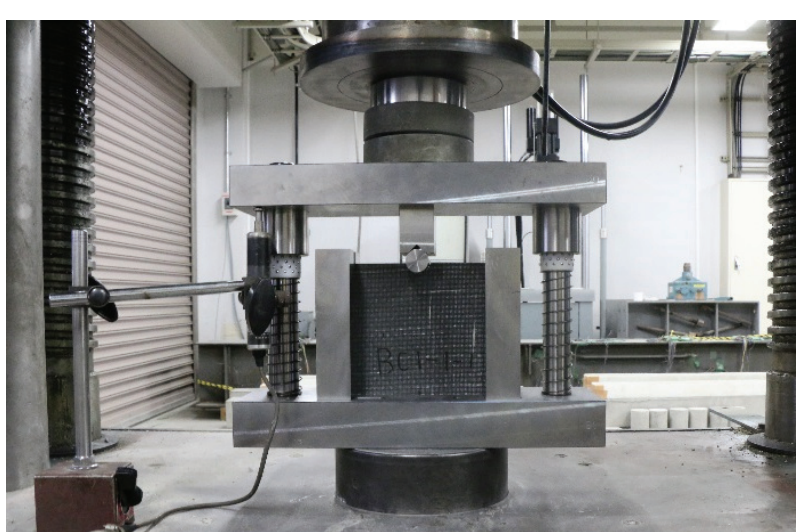

(b) Mottram 法

図-2 支圧試験の様子 
が入らないような半ねじボルトを使用した.

\section{（2）Mottram法による支圧試験}

本試験は Mottram ら のが ASTM D5764-97a で規定され た木材の支圧試験を参考にして提案した支圧試験法を使 用する．載荷試験には前川式万能試験機を用いた．図1(b)に試験方法の模式図，図-2(b)に支圧試験の様子を示 寸.

図-3(b)に Mottram 法の支圧試験体の寸法を示寸．試験 体は，長さと幅がピンの直径の 6倍の正方形の板で，上 部に直径 21mm の半円孔があけられている.

試験体の側面のみが接触するように試験体をホルダー の溝に設置し，試験体の上端の半円孔にピンを上から押 しつけ，鉛直方向に圧縮荷重を載荷することで支圧強度 を評価する. 支圧面とボルトのネジ部の接触によって, 支圧面が応力集中を受けて支圧強度が低下寸るのを防ぐ ために平滑な直径 20mm のピンを使用する．載荷速度は $0.01 \mathrm{~mm} / \mathrm{s}$ とした. 載荷治具上板に下側から変位計を当て ることで治具の変位を測定し，その変位を試験体の変位
とみなす，各積層体につき，5体ずつ試験を行った。

本試験は，支圧強度に関してピン接合法と同等の評価 ができると報告 のわされており，また，ピン接合法に比 べて試験体も小さくできるため，ピン接合法では長さが 足りず試験が行えないような部材に対しても適用でき, さらに様々な載荷方向に対しても試験体の切り出し方向 を変化させることで対応できるという利点がある.

\section{4. 支圧試験結果と考察}

ピン接合法および Mottram 法による支圧試験の荷重一 変位関係の例として，それぞれの試験方法での試験体 6 の1体目の荷重一変位関係を図-4に示寸．ピン接合法で は荷重が小さい領域で変位が大きく出ているが，これは ピン接合法による支圧試験では，ボルトと試験体の間に 隙間が存在し，荷重が小さい時点でこの隙間を埋めるた めの変位が出たことが原因である. また, 両試験法で, 最大荷重に達した後は, 荷重が少し減少したのち, 非常
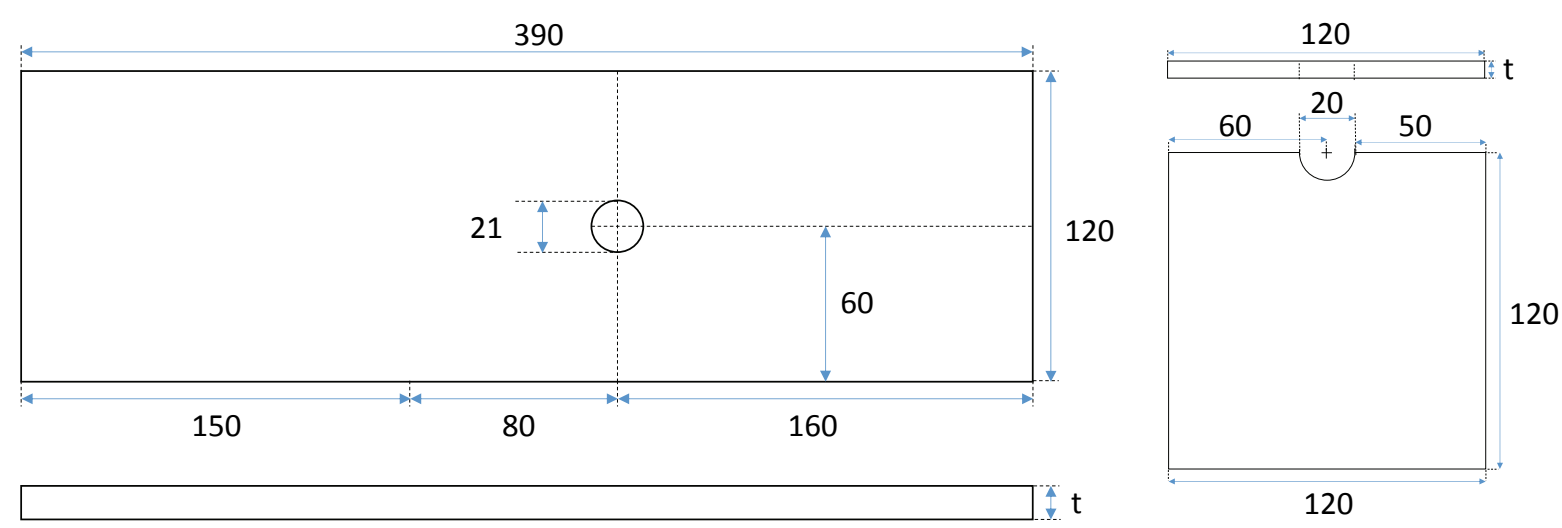

(a) ピン接合法の支圧試験体寸法

(b) Mottram 法の支圧試験体寸法

図-3 支圧試験体寸法

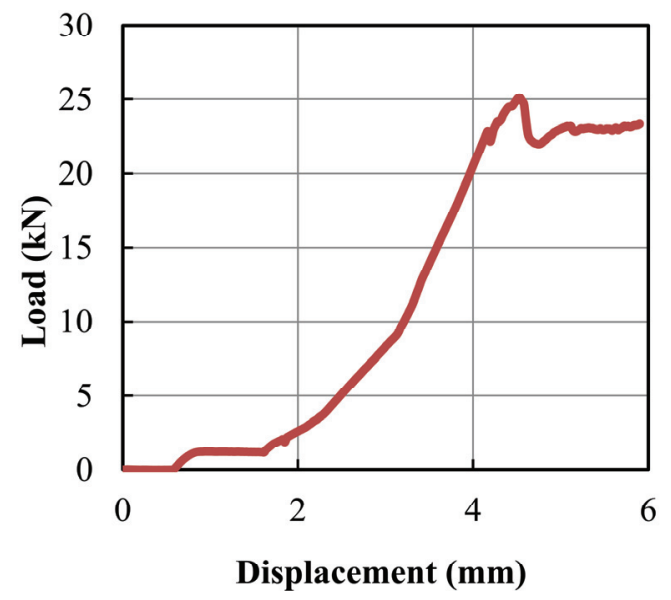

(a) ピン接合法

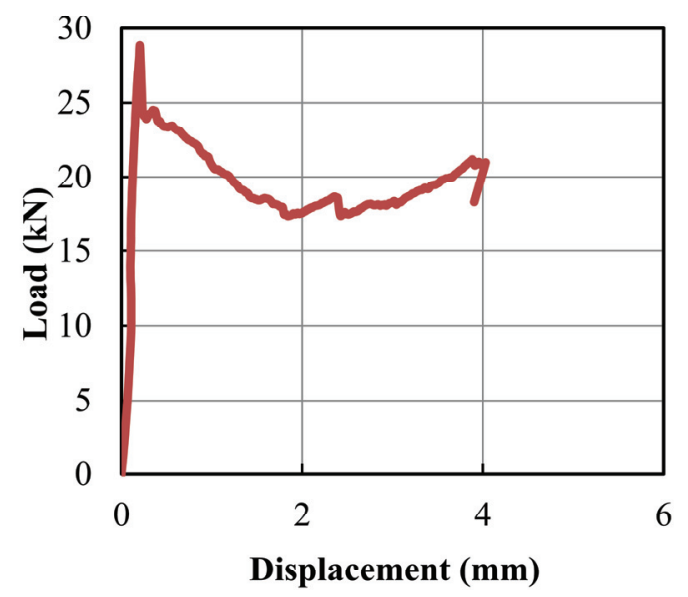

(b) Mottram 法

図-4 支圧試験の荷重一変位関係 
に緩やかに荷重が減少する挙動が見られた．Mottram 法 による支圧試験で最大荷重後の荷重の低下がピン接合法 に比べて大きいのは，Mottram 法では試験体がボルト孔 位置で切断されており，ボルト孔中心位置より上側の板 による拘束がないため, 支圧部での破壊に伴い，半円孔 付近で䋊維層間剥離が進展しや寸いためであると考えら れる.

表-5 と図-5に Mottram 法とピン接合法による支圧試験 によって得られた支圧強度結果をまとめる. 図-5 の棒 グラフは各 FRP 積層体の支圧強度の平均值を示してお り, 平均值士標準偏差の範囲を合わせて示している.
Mottram 法により得られた支圧強度は，ガラス䋊維のみ の FRP 積層体である試験体 7 で最も大きく, 351MPa で あった．残りの試験体 1 から試験体 6 では, 高強度の炭 素䋊維一方向材を使用した試験体 1 が大きく, 265MPa であり，他の試験体 2 から試験体 6 ではあまり大きな差 はなく, 約 200MPa であった. これらの結果から, 支圧 強度に関しては，䋊維方向の違いによる影響は大きくな く，炭素繊維かガラス䋊維かの繊維の種類による影響が 大きいことが明らかとなった。

また，Mottram 法およびピン接合法による支圧試験後 の試験体の様子を図-6 それぞれに示す. 全ての試験体

表-5 支圧試験結果

\begin{tabular}{|c|c|c|c|c|c|c|c|c|}
\hline \multicolumn{2}{|c|}{} & 試験体 1 & 試験体 2 & 試験体 3 & 試験体 4 & 試験体 5 & 試験体 6 & 試験体 7 \\
\hline \multirow{3}{*}{ Mottram 法y } & 支圧強度(MPa) & 265 & 190 & 202 & 201 & 206 & 216 & 351 \\
\cline { 2 - 9 } & 標潐偏差(MPa) & 22.7 & 13.6 & 6.92 & 8.29 & 12.3 & 15.1 & 24.4 \\
\cline { 2 - 9 } & 変動係数 & 0.086 & 0.071 & 0.034 & 0.041 & 0.059 & 0.070 & 0.070 \\
\hline \multirow{3}{*}{ ピン接合法 } & 支圧強度(MPa) & - & - & - & - & 169 & 183 & - \\
\cline { 2 - 9 } & 標淮偏差(MPa) & - & - & - & - & 8.12 & 3.35 & - \\
\cline { 2 - 9 } & 変動係数 & - & - & - & - & 0.048 & 0.018 & - \\
\hline
\end{tabular}

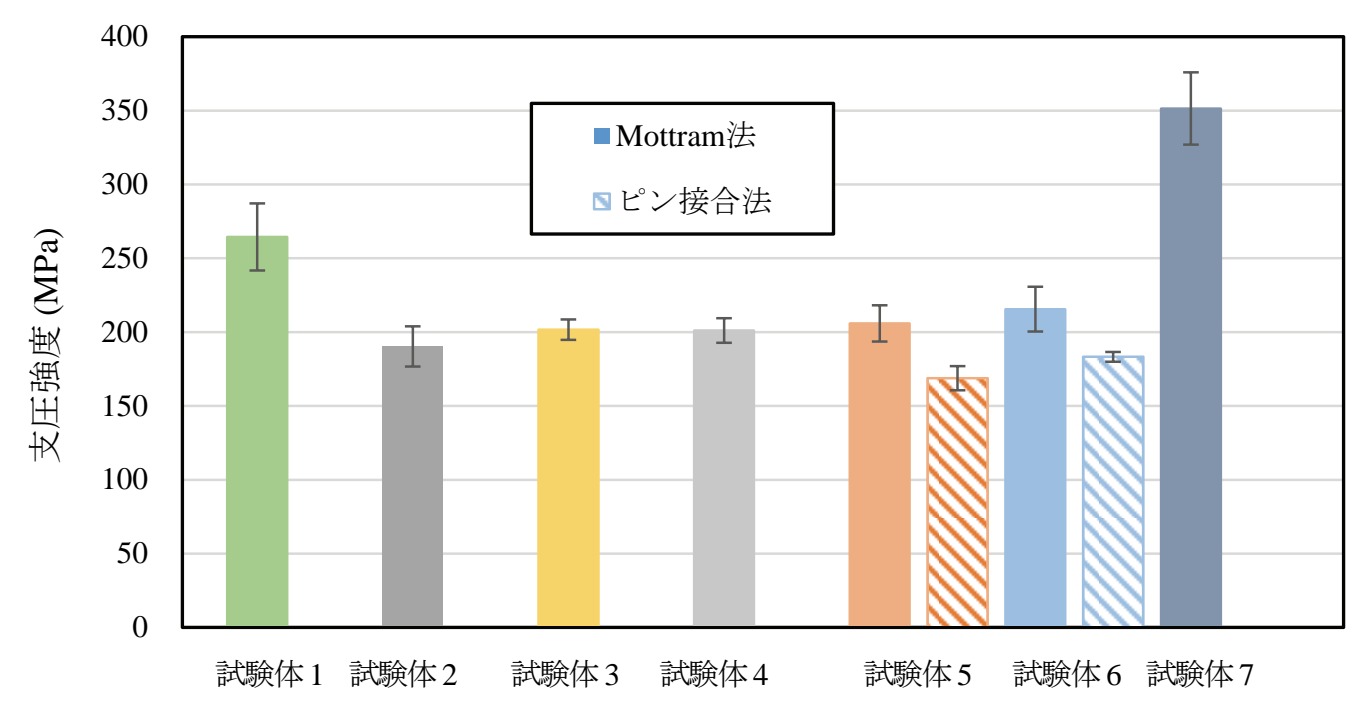

図-5 支圧強度の比較

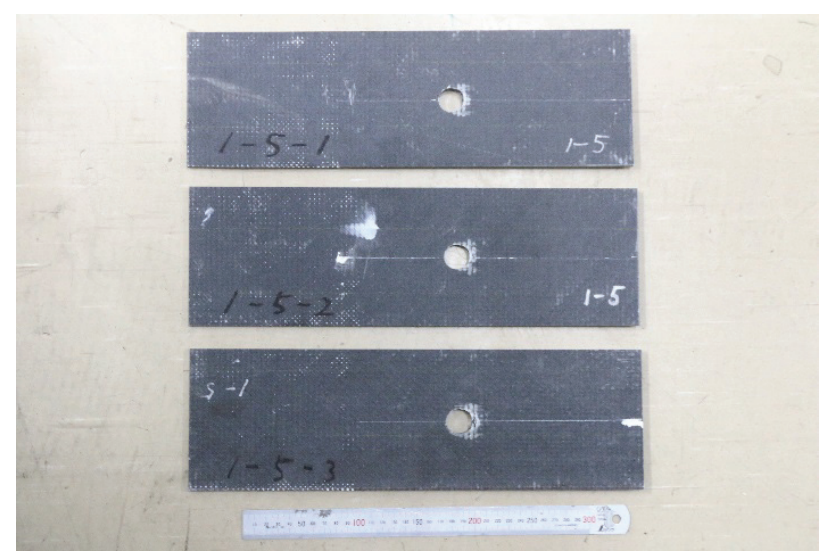

(a) ピン接合法

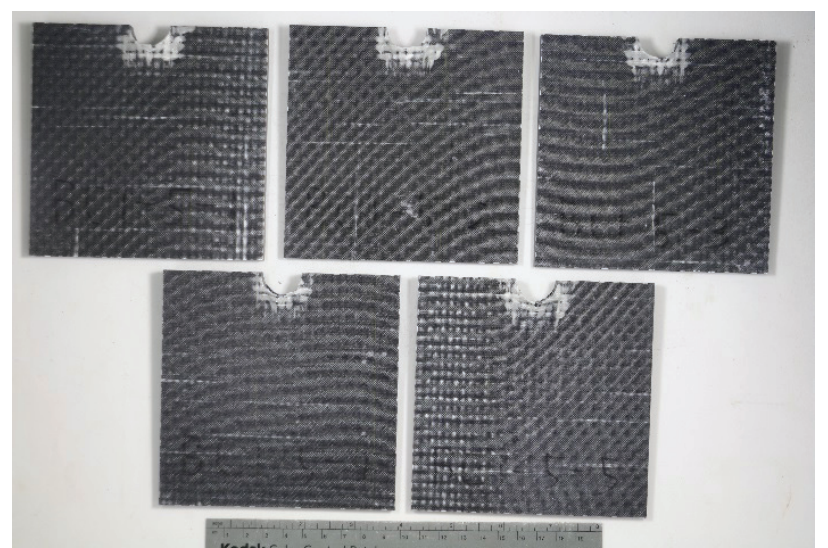

(b) Mottram 法

図-6＼cjkstart試験後の支圧試験体 


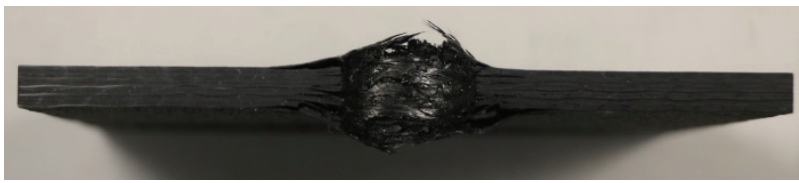

(a) 試験体 6

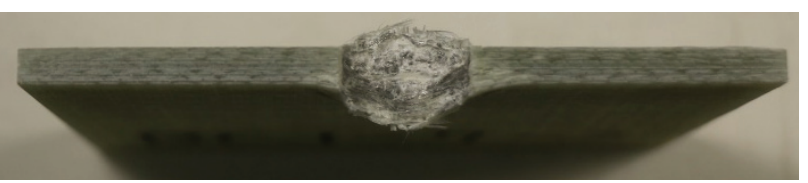

(b) 試験体 7

図-7 支圧破壊後の支圧部の様子

表-6 ピン接合法と Mottram 法の支圧強度の比

\begin{tabular}{|l|c|c|c|c|c|c|c|}
\hline & 試験体 1 & 試験体 2 & 試験体 3 & 試験体 4 & 試験体 5 & 試験体 6 & 試験体 7 \\
\hline 強度の比 (ピン接合/Mottram) & - & - & - & - & 0.82 & 0.85 & - \\
\hline
\end{tabular}

表-7 支圧強度の圧縮強度に対する比

\begin{tabular}{|c|c|c|c|c|c|c|c|}
\hline & 試験体 1 & 試験体 2 & 試験体 3 & 試験体 4 & 試験体 5 & 試験体 6 & 試験体 7 \\
\hline Mottram 法 & 0.65 & 0.57 & 0.56 & 0.57 & 0.49 & 0.60 & 0.93 \\
\hline ピン接合法 & - & - & - & - & 0.41 & 0.51 & - \\
\hline
\end{tabular}

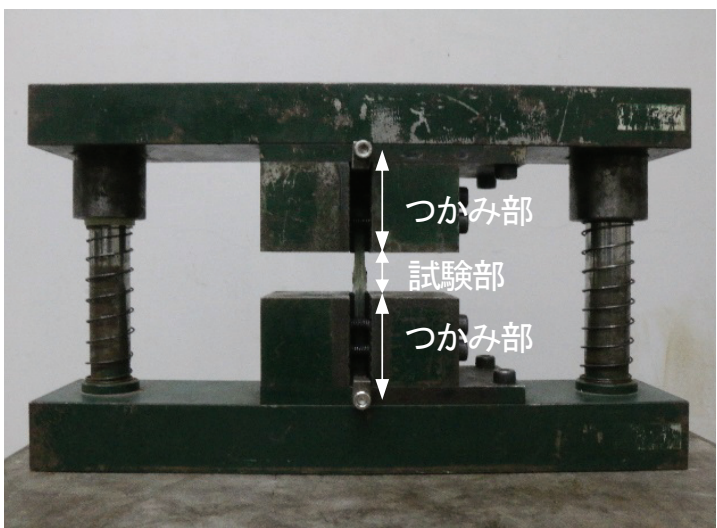

図-8 圧縮試験の様子

で支圧部が板厚方向にはらみ出す変形（ブルーミング） を示していた. Mottram 法でのブルーミングの様子を図7 に示す．実際のボルト接合部において， 2 面せん断で 両面に添接板がある場合には，この変形は添接板により 抑制される．また，一面せん断の場合も，片面は添接板 により変形が抑制され，もう片面はワッシャーが一部変 形を抑制するものと考えられる.

次に，表-6に試験体 5 と試験体 6 において試験方法間 の比較を行うと，ピン接合法の支圧強度が Mottram 法の 支圧強度よりも試験体 5 で約 18\%，試験体 6 で約 15\%小 さくなる結果となった。 ピン接合法では，M20 のボル 卜を使用して，その軸部が試験体に当たるように実験を 行ったが, Mottram 法に比べて, 支圧応力が板厚方向に 一様ではなかった可能性が支圧強度の違いの原因の一つ と考えられる. またもう一つの原因としてピン接合法と Mottram 法での試験体のボルト孔周りの拘束条件の違い が考えられる. Mottram 法では試験体上端が拘束されて いないために，支圧部がピンにより圧縮され半円孔が圧 縮方向に広がる変形と同時に試験体上端が幅方向内側に 収縮するような変形が可能な状況にある. 一方でピン接

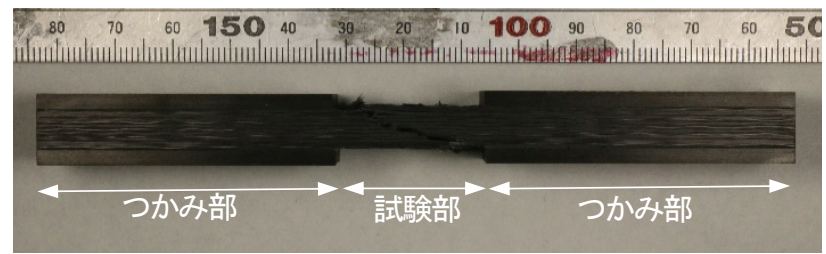

(a) 試験体 6

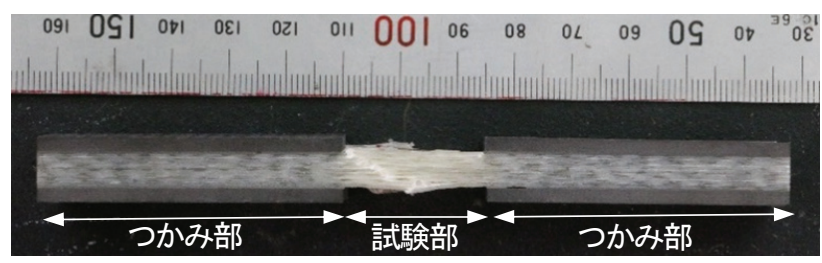

(b) 試験体 7

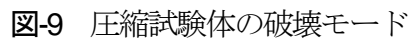

合法ではボルト孔位置で試験体が切断されていないため, 試験体が幅方向内側に収縮するような変形は拘束されて いる.このような拘束が存在するためにピン接合法では Mottram 法に比べてピンと試験体との接触面積が小さく なり，支圧強度が小さくなった可能性が考えられる。

したがって，Mottram 法で，ボルト接合部の支圧強度 を評価するためには，上記のようなピン接合法との違い を数值解析により詳細に検討し，さらに多くの試験を行 うことでデータの蓄積を行い，ピン接合法との関係性を 定量的に明らかにする必要がある.

ピン接合法は実際の支圧接合部の状態を表現できる試 験法であるが，試験方向に長く試験体を採取する必要が あり，本研究のように部材軸方向では問題なく試験体が 採取できても，部材直角方向やその他の方向の支圧強度 を試験的に得る必要があれば困難が生じる場合がある. ピン接合法と Mottram 法の支圧強度の関係性が明らかに なれば，そのような場合に Mottram 法を支圧強度評価法 として用いることが可能となる. 
また，各支圧試験方法で得られた支圧強度の材料圧縮 強度に対する比を表-7 に示す. Mottram 法とピン接合法 ともに試験体 7 以外の積層体で, 支圧強度は圧縮強度に 比べて大幅に小さくなることが明らかになった。

Mottram 法の支圧強度は試験体 1 から試験体 6 で圧縮強 度の約 50〜65\%，ピン接合法の支圧強度は圧縮強度の約 40〜50\%であった．ただし，強化繊維にガラス繊維のみ を使用した試験体 7 では，支圧強度は圧縮強度の約 93\% であり，その差は小さかった。試験体 7でのみ支圧強度 と圧縮強度の差が見られなかった理由としては積層構成 内の炭素繊維の有無が関係していることが考えられる.

図-7 に試験体 6 と試験体 7 の支圧破壊後の支圧部の様 子を示した，炭素繊維のみを使用した試験体 6 の支圧部 では繊維層間での剥離が多く見られ，特に最外層が大き く剥離していることがわかる。一方でガラス䋊維のみを 使用した試験体 7 の支圧部では繊維層間での剥離はあま り見られない，これは，䋊維径がより小さい炭素繊維が ガラス繊維に比べて繊維の座屈が生じやすく, ブルーミ ング現象が起こりやすいことに起因している.また，図 -8 に材料圧縮試験の試験の様子, 図-9 に材料圧縮試験 体の破壊モードを示寸，材料圧縮試験では，試験部の両 端が試験治具により拘束されているためブルーミングが 抑制されているが，支圧試験では自由にブルーミング変 形が生じることが，構成基材に炭素繊維を含む試験体 1 から試験体 6で，圧縮強度と支圧強度の間に大きな差を 生んだ原因として考えられる。
したがって，ガラス繊維のみの FRP 積層体の場合， 支圧強度を JIS K 7018 の圧縮試験で得られる圧縮強度で 代用しても，大きな誤差を生じないが，炭素繊維を使用 したハイブリッド FRP 積層体の支圧強度をこの圧縮強 度で代用することは難しいことが明らかとなった。

\section{5. ボルト軸力が支圧強度に与える影響}

4 章で述べたように, Mottram 法とピン接合法の両方 の支圧試験法で, 支圧試験体の支圧部が板厚方向にはら み出寸変形（ブルーミング）が確認された。しかし，実 際のボルト接合部で 2 面せん断の場合, 母板の両面に添 接板があるため，ブルーミングが抑制され，これらの支 圧試験とはボルト孔周りの応力状態が異なり, 支圧強度 も異なることが予想され, 既往の研究においても GFRP と CFRP ともに拘束効果による支圧強度の上昇が報告さ れている 8,9.9.そこで本研究においても，実際のボルト 接合部を想定し，ボルト軸力によるブルーミング変形の 抑制が支圧強度に与える影響について実験的に検討を行 った.

ここでは，3 章で示したピン接合法による支圧試験と 同様の方法で支圧試験を行う，トルクレンチを用いて 3N.m のトルク (手締め程度) でボルトを締めつけるこ とでボルト軸力を導入し，FRP 試験体と鋼製添接板の間 のスペースをなくした状態で引張荷重を載荷した。試験

表-8 ボルト軸力を導入した支圧試験の支圧強度とピン接合法の支圧強度

\begin{tabular}{|c|c|c|}
\hline & 試験体 5 & 試験体 6 \\
\hline ボルト軸力を導入した場合の支圧強度(MPa) & 497 & 689 \\
\hline 強度の比（ボルト軸力導入ピン接合） & 1.7 & 2.2 \\
\hline
\end{tabular}

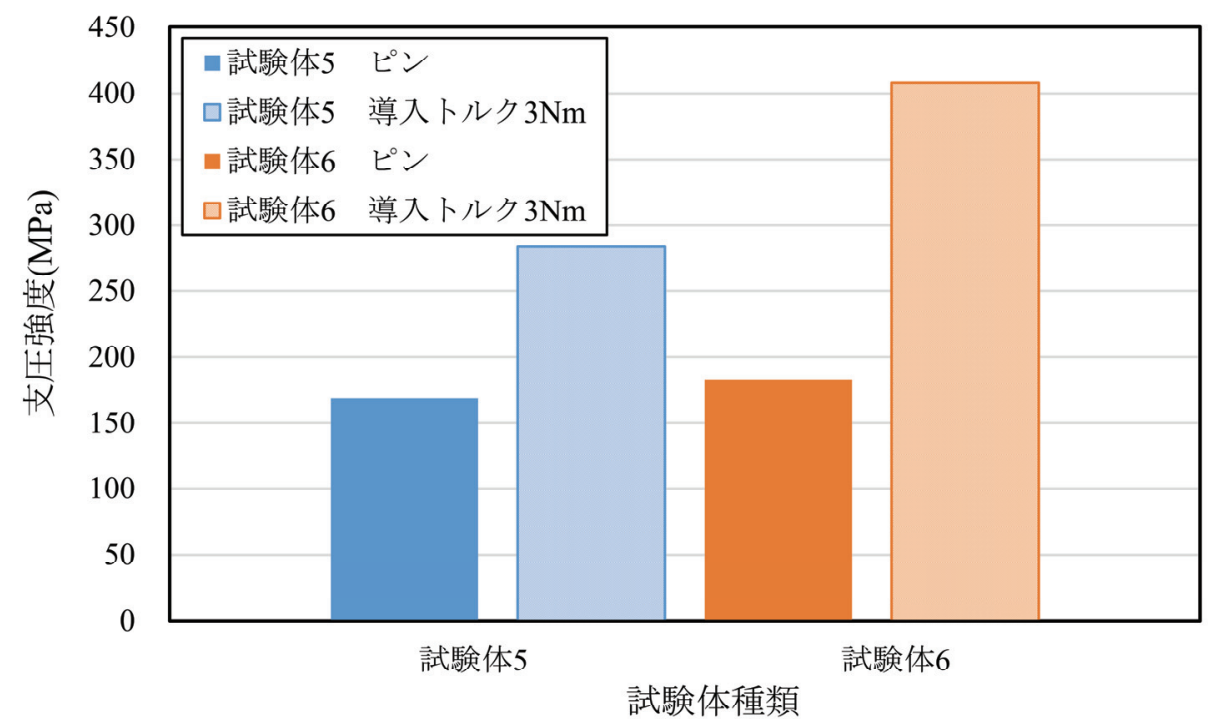

図-10 ボルト軸力を導入した支圧試験での支圧強度とピン接合法での支圧強度の比較 


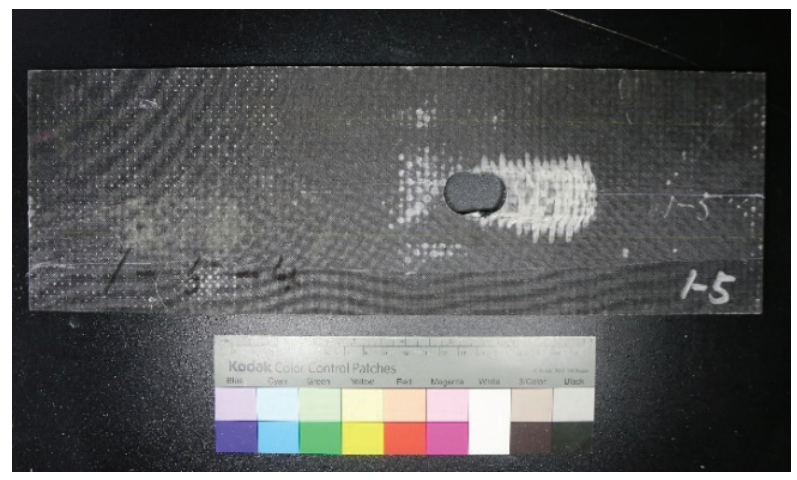

図-11 ボルト軸力を導入した試験体 6-4の試験後の様子

体は積層構成 5 と 6 を使用して，3 体ずつ製作した。ま た，摩擦力を期待していないため，全ての試験体で表面 処理は行っていない.

手締め程度のボルト軸力を導入した場合の支圧試験結 果とピン接合法による支圧試験結果の比較を表-8 と図10 に示す. 試験体 5 と試験体 6 ともにボル卜軸力を導 入することで，ピン接合での場合に比べて支圧強度が大 幅に増加することが確認できた．試験体 5 ではボルト軸 力を導入した場合の支圧強度が，ピン接合での支圧強度 の約 1.7 倍，試験体 6 では約 2.2 倍であった. したがっ て，ボルト軸力導入により，添接板が，試験体の支圧部 で板厚方向へのはらみ出し変形を抑制することで，ピン 接合の場合に比べて支圧強度が増加寸ることが確認でき た.

また，図-11 にボルト軸力を導入した支圧試験体の試 験後の様子を示寸．本試験では FRP 試験体と鋼製の添 接板を密着させていたが，試験体の支圧部分では，最終 的には添接板を外側に押し出すようにして，ピン接合法 の場合と同様に，板厚方向へのはらみ出しが見られた。

また図-12 にボルト軸力を導入した支圧試験体 6-4 の 支圧試験における荷重が小さい領域での荷重一変位関係 を示す. 荷重 $2 \mathrm{kN}$ 時ですべりが生じすべり耐力に達し たことがわかる．ただし本研究では導入トルクが $3 \mathrm{~N} \cdot \mathrm{m}$ と小さかったため, す心゙り耐力は最大支圧耐力（65kN） と比較して約 3\%と非常に小さく, 支圧耐力に及ぼす摩 擦の影響は小さいと考えられる.

ボルト軸力を導入した場合の支圧強度については，ボ ルト軸力の大きさと支圧強度との関係を定量的に明らか にするため, さらなる実験的検討が必要である.

\section{6. 結論}

本研究では 5 種類のハイブリッド FRP 積層体および, CFRP 積層体，GFRP 積層体を対象とし，ピン接合法に よる支圧試験と Mottram 法による支圧試験を実施し, 得

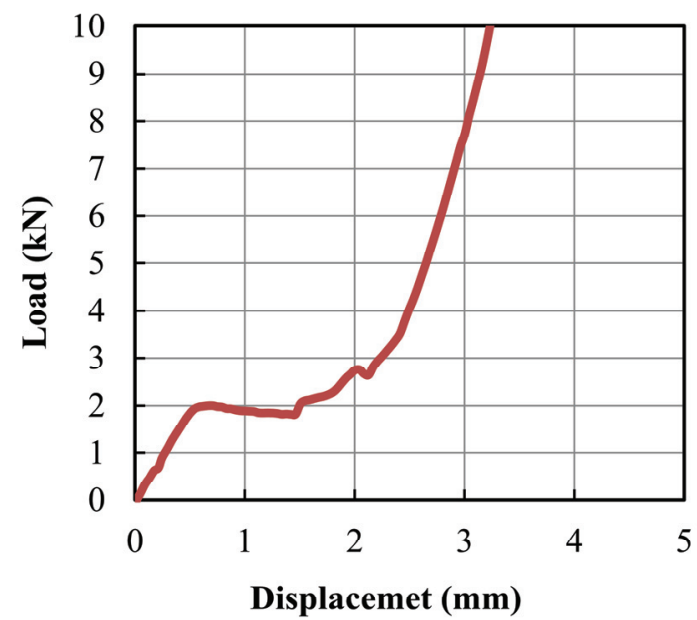

図-12 試験体 6-4 の荷重が小さい領域での荷重一変位関係

られた試験結果の比較を行うことで, 異なる積層構成が 支圧強度に与える影響を明らかにし，異なる試験方法間 での支圧強度の違いについても検討した．また，材料圧 縮試験を行って, 支圧強度と圧縮強度を比較をすること で, 異なる積層構成における支圧強度と圧縮強度の関係 について検討した. さらに, ボルト軸力が支圧強度に与 える影響について検討するために，手締め程度のトルク を導入した支圧試験を行った．以上の検討を行うことで, 以下の結論を得た。

（1）ピン接合法の支圧強度は Mottram 法の支圧試験の支 圧強度に比べて約 20\%小さくなることが明らかに なった。

（2）試験体 1 から試験体 6 の積層体では支圧強度は圧 縮強度の約 40〜65\%となり, 支圧強度は圧縮強度 に比べて大幅に小さくなることが明らかになった. ただし，ガラス繊維のみを用いた試験体 7 では, 圧縮強度の約 93\%であり, 大きな違いは見られな かった.

（3）ボルト締結時に $3 \mathrm{~N} \cdot \mathrm{m}$ のトルクを与えて手締め程度 のボルト軸力を導入することで, 添接板により支 圧部の板厚方向へのはらみ出し変形（ブルーミン グ）が抑制され，支圧強度がピン接合法に比べて 約 2 倍に増加することが明らかになった。

Mottram 法とピン接合法の支圧強度の関係性や，ボル 卜軸力と支圧強度との関係性は, 今後さらなるデータの 蓄積を行う必要がある.

謝辞 : 本研究は, 地域住民生活等緊急支援交付金（地方 創生先行型）を受け，福井県が中心となって平成27年度 に実施した研究プロジェクトの一部である.ここに深く 感謝の意を表します。 


\section{参考文献}

1) 名取暢：鋼橋の腐食事例とその対策, 溶接学会全国 大会講演概要, pp.15-18, 1994.

2) Vo Thanh Hung, 永澤洋, 佐々木栄一, 市川篤司, 名 取暢：腐食が原因で取り替えられた実鋼橋支点部の 載荷実験および解析，土木学会論文集，No.710， pp.141-151, 2002.

3) 土木学会複合構造委員会 : 複合構造レポート09 FRP 部材の接合および鋼と FRP の接着接合に関する先端 技術，丸善，pp.3-42， 2013.

4) 土木学会構造工学委員会 : FRP 橋梁一技術とその展 望一, 土木学会, 264p., 2004.

5）飯田達也, 前田研一, 中村一史, 睦好宏史, 松井孝 洋, 鈴川研二, 吉田一, 柳沼謙一：ハイブリッド FRP 部材のボルト接合における支圧強度とガルバニ ック腐食に関する検討, 土木学会第 65 回年次学術講 演会講演概要集, CS2-011, pp.21-22, 2010.

6) Mottram, J. T. and Zafari, B.: Pin-bearing strengths for bolted connections in fiber-reinforced polymer structures,
Structures and Buildings, Vol.164, No.SB5, pp.291-305, 2011.

7) Matharu, N. S. and Mottram, J. T.: Laterally unrestrained bolt bearing strength: Plain pin and threaded values, Proc. of the 6th International Conference on FRP Composites in Civil Engineering (CICE 2012), Rome, Section 14: Codes and Design Guidelines, Paper 311 (CD-ROM), 2012.

8) Xiao, Y. and Ishikawa, T.: Bearing strength and failure behavior of bolted composite joints (part I: Experimental investigation), Composites Science and Technology, Vol.65, pp.1022-1031, 2005.

9) Mottram, J. T.: Determination of pin-bearing strength for the design of bolted connections with standard pultruded profiles, Proc. of the 4th International Conference on Advanced Composites in Construction, Edinburgh, Scotland, pp.483-495, 2009.

(2016. 12.26 受付)

\title{
EXPERIMENTAL STUDY ON BEARING STRENGTH EVALUATION METHOD OF HYBRID FRP LAMINATES
}

\author{
Yuta UEYAMA, Yasuo KITANE, Takahiro MATSUI, Fujio KONDO \\ and Kazuo TATEISHI
}

The purpose of this study is to evaluate bearing characteristics of a bolted joint of hybrid FRP members. Therefore, in this study, the bearing test suggested by Mottram et al. and the pin joint bearing test were performed on five different hybrid FRP laminates consisting of both carbon fiber and glass fiber, CFRP laminate and GFRP laminate, and test results were compared. Then, the influence of different FRP types or stacking sequences on bearing strength was examined. Results showed that bearing strength could be about fifty percent of compressive strength depending on the type or the laminated structure of the reinforcing fibers. The bearing strength from the Mottram method was found to be smaller by about 20 percent than that from the pin joint method. Finally, the effect of bolt axial force on bearing strength was examined, and the significant increase of bearing strength due to the bolt axial force was confirmed. 